\title{
First record of necrophagy by Scybalocanthon nigriceps Harold (Coleoptera, Scarabaeidae, Scarabaeinae)
}

\author{
Yuri F. Messas ${ }^{1}$, Hebert S. Souza ${ }^{1}$, Gustavo Schiffler ${ }^{1} \&$ Jober F. Sobczak ${ }^{2}$ \\ ${ }^{1}$ Programa de Pós-graduação em Ecologia, Departamento de Biologia Animal, Instituto de Biologia, Universidade Estadual de Campinas, 13083-862, \\ Campinas-SP, Brazil.yurimessas@gmail.com; hssouza.bio@gmail.com; tataschiffler@gmail.com \\ ${ }^{2}$ Programa de Pós-graduação em Ecologia e Recursos Naturais, Departamento de Ecologia e Biologia Evolutiva, Universidade Federal de São Carlos, \\ 13565-905, São Carlos-SP, Brazil. jobczak@gmail.com
}

\begin{abstract}
First record of necrophagy by Scybalocanthon nigriceps Harold (Coleoptera, Scarabaeidae, Scarabaeinae). The $S$. nigriceps specimen was observed making small cuts and removing portions of the carcass of a frog Haddadus binotatus (Spix) in February 24, 2011, in Serra do Japi, São Paulo State, Brazil. This note presents another record of necrophagy for Scybalocanthon.

KEYWORDS. Atlantic Forest; biodiversity; dung beetle; interaction.

RESUMO. Primeiro relato de necrofagia por Scybalocanthon nigriceps Harold (Coleoptera, Scarabaeidae, Scarabaeinae). O espécime de S. nigriceps foi observado fazendo pequenos cortes e removendo porções da carcaça da rã Haddadus binotatus (Spix) em 24 de fevereiro de 2011 na Serra do Japi, Estado de São Paulo, Brasil. Esta nota apresenta mais um registro de negrofagia para Scybalocanthon.
\end{abstract}

PALAVRAS-CHAVE. Mata atlântica; biodiversidade; escaravelhos; interação.

The family Scarabaeidae is widely distributed, with around 7000 species in the world (Schoolmeesters et al. 2011). The subfamily Scarabaeinae contains detritivorous beetles, known as "dung beetles", which make, roll, and bury portions of organic material that serves as substrate for oviposition, as well as food for the larvae. The resource allocation behavior of these beetles has an important ecological role, because it removes and reinstates organic material in the soil (Halffter \& Matthews 1966). The main eating habits are saprophagy, coprophagy, and necrophagy (Hanski \& Cambefort 1991), which evolved in this sequence from the availability of resources along the evolutionary trajectory of the group (Davis et al. 2002). According to the same author, coprophagy in the group possibly occurred between the Mesozoic and Cenozoic, the period when mammals began to dominate the earth. Necrophagy in dung beetles is a derived condition that probably arose in tropical forests along with climate changes and species extinction of large vertebrates which were the excrement producers that gave support to the coprophagous habit of this group (Halffter \& Matthews 1966).

Necrophagy is poorly recorded for the genus Scybalocanthon Martínez, 1948. Scybalocanthon moniliatus (Bates, 1887) was reported on the carcasses of skunk, peccary, rat, snake, and sloth on Barro Colorado Island in Panama (Howden \& Young 1981). The species of this genus occur widely in wet and dry forests, distributed from Central America to South America. Studies of the biology of some species showed that they exhibit preferentially diurnal activity and are easily collected with traps baited with excrement (Martínez \& Halffter 1972; Howden \& Young 1981; Spector \& Ayzama 2003; Hernández \&Vaz-de-Mello 2009). Corroborating this information for the genus, Scybalocanthon nigriceps (Harold, 1868), is a diurnal species, which prefers shaded areas and is attracted to feces (Hernández 2002; Hernández \& Vaz-de-Mello 2009).

We report in this note a new record of necrophagy for the genus Scybalocanthon. We made observations of this behavior and photographic records between 13:40 and 14:00 h on February 24, 2011, on a road known as Paraíso III (2315' 28"S', 4656'51"W"), at an elevation of $990 \mathrm{~m}$, in Serra do Japi, São Paulo State, Brazil. The observed material was collected, enclosed in a plastic recipient containing 70\% alcohol, and deposited in the collection of Museu de Zoologia da Universidade Estadual de Campinas, São Paulo State.

We observed a female of $S$. nigriceps removing portions of a carcass of the tree frog Haddadus binotatus (Spix, 1824) (Fig. 1), which was still intact and newly dead. The beetle took a piece of carrion big enough to shape a pellet (Fig. 2), using its front legs and clypeus. The event lasted about six minutes.

To say that $S$. nigriceps is generalist, i.e., that both feeds on feces and carcasses, it would be necessary to collect samples with different types of bait to determine their food preference. Feer \& Pincebourde (2005) consider that to classify species as 

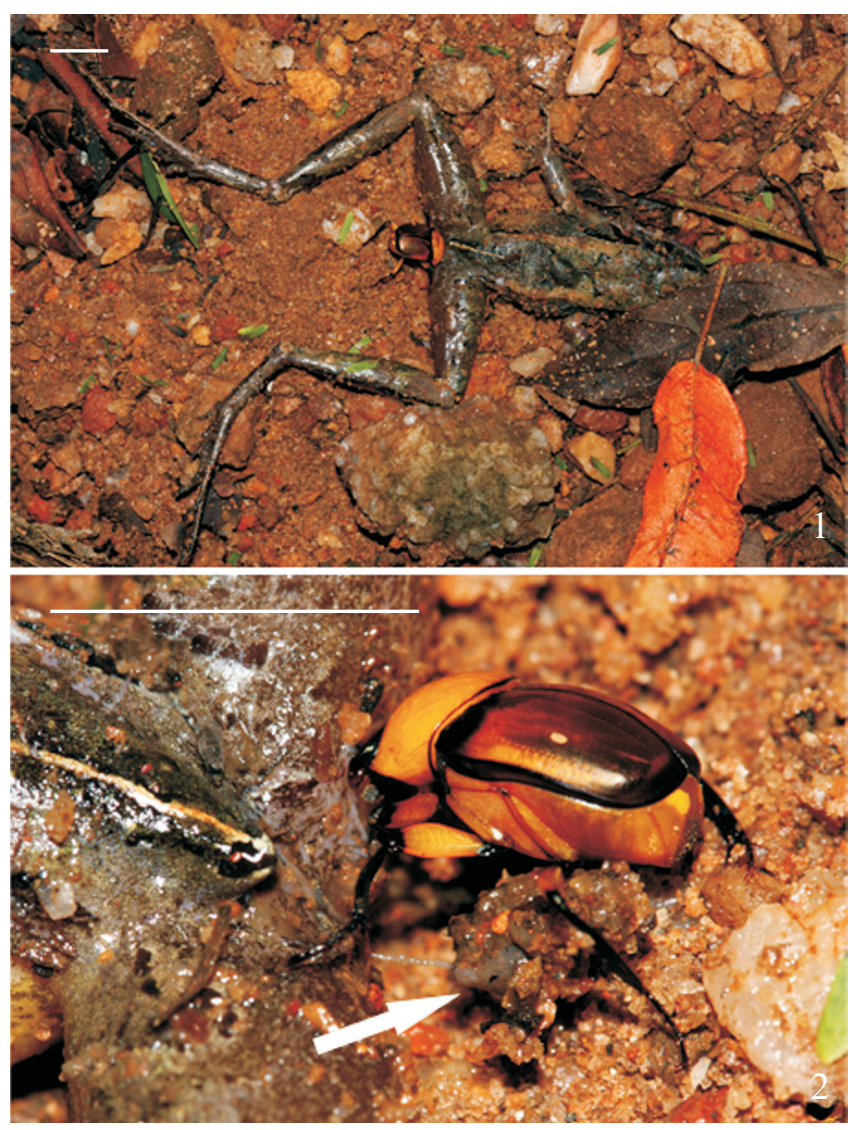

Figs. 1-2. Necrophagy by Scybalocanthon nigriceps in carcass of $H$. binotatus. 1, dorsal view of frog carcass being used by $S$. nigriceps to make the pellet. 2, Detail of a portion of carcass removal to pellet's confection. The arrow points to the pellet. Scale bars: $1 \mathrm{~cm}$.

specialists it is necessary that $90 \%$ or more of the individuals are caught with only one type of bait. Therefore, the observed event can be only occasional, and further studies on the feeding preferences of this group are necessary.

\section{ACKNOWLEDGMENTS}

We would like to thank Dr. Silvio César de Almeida and Dr. Fernando Z. Vaz-de-Mello for the identifications of the frog and beetle, respectively, and Dr. João Vasconcellos Neto for critical reading of this note. This work was supported by Conselho Nacional de Desenvolvimento Científico e Tecnológico (CNPq - research grants to J. F. Sobczak). Also, we thank the Prefeitura Municipal de Jundiaí.

\section{REFERENCES}

Davis, A. L. V.; C. H. Scholtz, \& T. K. Philips. 2002. Historical biogeography of Scarabaeinae dung beetle. Journal of Biogeography 29: 1217-1256.

Feer, F. \& S. Pincebourde. 2005. Diel flight activity and ecological segregation with in an assemblage of tropical forest dung and carrion beetles. Journal of Tropical Ecology 21: 21-30.

Halffter, G. \& E. G. Matthews. 1966. The natural history of dung beetles of the subfamily Scarabaeinae (Coleoptera: Scarabaeidae). Folia Entomológica Mexicana 12/14: 1-312.

Hanski, I. \& Y. Cambefort. 1991. Dung Beetle Ecology. Princeton, Princeton University Press, $520 \mathrm{p}$.

Hernández, M. I. M. 2002. The night and day of dung beetles (Coleoptera, Scarabaeidae) in the Serra do Japi, Brazil: elytra colour related to daily activity. Revista Brasileira de Entomologia 46: 597-600.

Hernández, M. I. M. \& F. Z. Vaz-de-Mello. 2009. Seasonal and spatial species richness variation of dung beetle (Coleoptera, Scarabaeidae $s$. str.) in the Atlantic Forest of southeastern Brazil. Revista Brasileira de Entomologia 53: 607-613.

Howden, H. F \& O. P. Young. 1981. Panamanian Scarabaeinae taxonomy, distribution and habits (Coleoptera: Scarabaeidae). Contributions of the American Entomological Institute 18: 1-204.

Martínez, A. \& G. Halffter. 1972. New taxa of American Canthonina. Entomologische Arbeiten aus dem Museum G. Frey 23: 33-66.

Schoolmeesters, P.; A. L. V. Davis; W. D. Edmonds; B. Gill; D. Mann; P. Moretto; D. Price; C. Reid; S. Spector \& F. Z. Vaz-de-Mello. 2011. ScarabNet Global Taxon Database (version 1.5). Available at: http:/ /216.73.243.70/scarabnet/results.htm (accessed on 1 August 2011).

Spector S. \& S. Ayzama. 2003. Rapid Turnover and Edge Effects in Dung Beetle Assemblages (Scarabaeidae) at a Bolivian Neotropical ForestSavanna Ecotone. Biotropica 35: 394-404.
Received 8/11/2011; accepted 11/4/2012

Editor: Marcela Laura Monné 